\title{
Quantitation of oxalates in corms and shoots of Colocasia esculenta (L.) Schott under drought conditions
}

\author{
Carla S. S. Gouveia ${ }^{1}$ (1) $\cdot$ José F. T. Ganança ${ }^{1,2} \cdot$ Vincent Lebot $^{3} \cdot$ Miguel Â. A. Pinheiro de Carvalho $^{1,2}$
}

Received: 27 February 2018 / Revised: 23 May 2018 / Accepted: 9 November 2018 / Published online: 23 November 2018

(c) Franciszek Górski Institute of Plant Physiology, Polish Academy of Sciences, Kraków 2018

\begin{abstract}
Oxalate (calcium oxalate) accumulation in taro plants (Colocasia esculenta (L.) Schott) impacts their nutritional quality, producing acridity, causing lips, mouth and throat tissues swelling if consumed fresh. The oxalate content is related to photosynthesis, through the glycolate-glyoxylate oxidation pathway. The plant's photosynthetic rate usually increases in non-stressed conditions. Differences in photosynthetic rate are indirectly related to the chlorophyll content index. Protein accumulation and starch variation are also important traits to understand the taro oxalate synthesis caused by drought and how they affect corm quality. The purpose of this study was to quantitate oxalates in taro corms and shoots submitted to drought conditions and to evaluate how stress response can affect the nutritional quality of taro whole-plant. Seven taro genotypes from Madeira, Canaries and Pacific Community (SPC) collections were grown in greenhouse conditions and submitted to different watering regimes for drought tolerance screening. Corms and shoots were harvested and evaluated for oxalates (soluble, insoluble and total), chlorophyll content index (CCI), crude protein, starch, starch solubility in water and starch swelling power. All accessions had very high calcium oxalate content. Drought-tolerant genotypes showed good osmotic response by oxalate precipitation and mobilization through shoot to corm tissues, photosynthesis adaptation by increase of $\mathrm{CCI}$, protein accumulation, and very low starch hydrolysis. Sensitive-drought genotypes showed less mobilization of calcium oxalate, decreased photosynthetic rate and protein synthesis, and slight increase of starch hydrolysis. Variation in taro oxalate content is consistent and significantly correlated with the photosynthetic rate, carbohydrate metabolism and protein synthesis.
\end{abstract}

Keywords Carbohydrate metabolism · Chlorophyll content index · Colocasia esculenta (L.) Schott · Drought tolerance · Photosynthesis · Soluble and insoluble oxalates

$\begin{array}{ll}\text { Abbreviations } \\ \text { Acc } & \text { Accession } \\ \text { ANOVA } & \text { Analysis of variance } \\ \text { CCI } & \text { Chlorophyll content index } \\ \text { CaOx } & \text { Calcium oxalate } \\ \text { KOx } & \text { Potassium oxalate } \\ \text { PCA } & \text { Principal component analysis } \\ \text { SPC } & \text { Pacific community } \\ \text { S-Ox } & \text { Soluble oxalates (oxalic acid) }\end{array}$

Communicated by R. Aroca.

Carla S. S. Gouveia

csgouveia@uma.pt

1 ISOPlexis Genebank, University of Madeira, Campus da Penteada, 9020-105 Funchal, Madeira, Portugal

2 ICAAM, University of Évora, Apartado 94, 7006-554 Évora, Portugal

3 CIRAD-BIOS, PO Box 946, Port Vila, Vanuatu
SSP Starch swelling power

SWS Starch solubility in water

T-Ox Total oxalates

\section{Introduction}

Taro, Colocasia esculenta (L.) Schott (Araceae), is probably one of the oldest crops on earth that has been grown on irrigated terraces in tropical Asia for more than 10,000 years (Lebot 2009). It is a staple food in tropical and developing countries, being an important source of carbohydrates, in the form of starch stored in the corms (Sharma and Kaushal 2016; Lebot 2009). According to FAOSTAT database (http:// www.fao.org, 2018), taro has the lowest yield of all root crops (cassava, sweet potato and yam). However, its worldwide yield had a slight decrease from $6.98 \mathrm{t} / \mathrm{ha}$ in 2010 to $6.06 \mathrm{t} / \mathrm{ha}$ in 2016 , still demanding for food security. To obtain optimal yields, the taro plant needs a very good water 
supply, but the water scarcity and severe weather events are expected to have a growing negative impact on this important subsistence crop (Ganança et al. 2015; Farooq et al. 2009).

Raw taro corms, petioles and leaves are considered toxic due to the presence of calcium oxalate $(\mathrm{CaOx})$ crystals (or raphides), which negatively affects their nutritional value and quality (Franceschi and Horner 1980).

Oxalate accumulation by plants is used as a protection mechanism against foraging animals, by producing acridity, causing lips, mouth and throat swelling, and kidney disorders if consumed fresh (Sharma and Kaushal 2016; Franceschi and Horner 1980). The calcium absorption and oxalic acid synthesis is important for the plant ion balance and osmoregulation, through the regulation of excess calcium ions by precipitation with oxalic acid, in the form of $\mathrm{CaOx}$ crystals. Generally, the intensity of the plants tissues acridity changes during the growing season. The acridity can be connected to drought, nutrient or genetic factors (Prasad and Shivay 2017; Sharma and Kaushal 2016; Libert and Franceschi 1987).

The plant oxalate synthesis is related to the photosynthetic glycolate-glyoxylate oxidation by light stimulation. The oxalate concentration usually increases during the hours of peak photosynthesis and decreases during the evening and night (Franceschi and Horner 1980). The glyoxylate can also be converted in oxalate via iso-citrate during acid metabolism in the dark, and by the Krebs cycle from sugars and certain protein amino acids (Burgess and Huang 2016; Franceschi and Horner 1980).

The leaf chlorophyll content measurement with optic detection is one of the common traits used for drought stress assessment. Differences in the photosynthetic rate can be indirectly assessed by the chlorophyll content index (CCI), where the canopy greenness is directly related with the plant's photosynthetic efficiency. During the day light, the glycolic acid is converted into oxalate, leading to an increase of oxalate production, which can be associated with the increase of the photosynthetic rate and chlorophyll content (Tiwari and Mamrutha 2013; Franceschi and Horner 1980). The photosynthetic rate increase is an indicator of the plant's ability to tolerate abiotic stress, where the better the plant resistance to drought, the higher will be the plant chlorophyll index (Salehi-Lisar and Bakhshayeshan-Agdam 2016; Mabhaudhi and Modi 2015; Tiwari and Mamrutha 2013).

The plant starch content variation and protein accumulation are important traits linked with oxalate metabolism, and are also the main traits for the corm nutritional quality assessment. During the photosynthesis, the carbohydrate synthesis supplies the plant tissues with metabolites needed for growth, energy production and signaling processes. The carbohydrate maintenance depends on the strength of the stress factor on the carbon metabolic pathways (Burgess and
Huang 2016). The carbohydrates oxidation provides energy for the nitrates reduction into protein nitrogen, where the oxalate is a direct subproduct (Franceschi and Horner 1980). Throughout drought stress, there is a reduction of the carbohydrate metabolism relative to photosynthesis, with accumulation of soluble sugars in detriment of increased starch hydrolysis, as a way to protect the subcellular structures against the negative effects of water deficit (Burgess and Huang 2016; Osuagwu and Edeoga 2013; Epron and Dreyer 1996). The drought affects the quantity and quality of plant proteins, and generally results in an increase of the crude protein content under stress. Plant tissues usually synthetizes specialized high molecular proteins as a resistance response to drought. The stress effect is minimized by proteins acting as cellular compartment space fillers (e.g., LEA proteins), or as natural osmoprotectants amino acids (e.g., proline) (Salehi-Lisar and Bakhshayeshan-Agdam 2016; Osuagwu and Edeoga 2013).

There are several studies on the biochemical composition of taro, but there is scarce information about drought stress effects and how the oxalate, protein and starch variation under stress can be reflected on its nutritional quality. There is data regarding the acridity and nutritional aspects (Kaushal et al. 2015; Temesgen and Retta 2015; Tattiyakul et al. 2006, 2007), the oxalates quantitation in raw and cooked leaves (Oscarsson and Savage 2007), processed flour (Iwuoha and Kalu 1995) and in corm chips (Kumoro et al. 2014) of non-stressed taro plants. The main research on drought tolerance of this crop is based on physiological traits and plant productivity assays, performed mainly under rain feed conditions (Mabhaudhi and Modi 2015). Recently, a genetic and phenotypic approach was used to screen taro stress sensitivity or tolerance to drought stress, by applying morpho-agronomic and yield stress indexes. There is the possibility of using the identified genetic diversity in breeding programs to adapt this crop to climatic change (Ganança et al. 2015, 2018; Lebot et al. 2017).

The aim of the present study was to improve our understanding on how drought-stressed taro plants changes their nutritional quality and biochemical composition, by assessing oxalate mechanisms and their interactions with the CCI, protein-nitrogen accumulation and starch variation to water shortage.

\section{Materials and methods}

\section{Plant material}

7 from 33 cultivars of Colocasia esculenta (L.) Schott were selected to assess the variation of plant biochemical composition under drought conditions. These seven cultivars, with origin in Madeira and Canary Islands, and from the Pacific 
Community (SPC) collection, were selected based on their morpho-agronomic and multi-criteria indices performance under drought conditions (Table 1) performed by Ganança et al. (2018) in 2014.

\section{Experimental drought conditions}

The present study was conducted during a plant full-growth cycle in 2015, under controlled conditions, in an open greenhouse in the Preces experimental station, Câmara de Lobos, Madeira, Portugal $\left(32^{\circ} 39^{\prime} \mathrm{N} ; 16^{\circ} 58^{\prime} \mathrm{W}\right)$. Plants were individually grown in $30 \times 30 \mathrm{~cm}$ pots, filled with $15 \mathrm{~kg}$ of dried soil. The pots were arranged in six rows, spaced $90 \mathrm{~cm}$ apart, and $30 \mathrm{~cm}$ in row separation. Twenty-four plants per accession, four per row, were submitted to two different watering regimes to assess the influence of drought conditions in biochemical parameters. Three rows were maintained at field capacity (control), and another three were submitted to water deficit (drought stress, $40.2 \%$ of water applied to control) from April to November 2015. Each row was considered a replicate. During drought assay, the greenhouse average temperature was $25.12{ }^{\circ} \mathrm{C}$, with an average relative humidity of $49.94 \%$. Experimental design and watering regimes were adapted from Ganança et al. (2018). During full-growth cycle, no pesticide or fertilizer was used and weeds were manually removed as necessary.

\section{Sample preparation}

Three hundred and thirty-six corm and shoot (petioles and leafs) samples of control and drought rows were harvested at the end of the agronomic assay. All samples were cleaned with running water, measured with a caliper rule (Mitutoyo solar digimatic caliper CD-S15C, Japan), weighed with a scale (Sartorius Basic BA2100S, Germany), sliced (2-3 mm thick) with a mandolin slicer, dehydrated using an air oven at $65{ }^{\circ} \mathrm{C}$, for $48 \mathrm{~h}$ (Memmert UF260, Germany) and finely milled (IKA-Werke M20, USA). The flour was placed into bags (Termofilm PA/PE), vacuum sealed (Audionvac
VMS153, Netherlands) and stored at $-35^{\circ} \mathrm{C}$ (Liebherr ProfiLine GGPV6570, Germany) until analysis.

\section{Chlorophyll content index (CCI)}

The CCI was determined in fresh taro leaves, with a chlorophyll content meter (Opti-Sciences CCM-200 PLUS, USA). The CCM-200 calculates the CCI as the ratio between leaf transmission percentages at $932 \mathrm{~nm}$ (reference wavelength) and $653 \mathrm{~nm}$ (absorbed by molecules, other than chlorophyll). The measurements were done between 9.00 and 11.00 a.m., in the main plant's fully unfolded leaf. The reading was made uniformly along the adaxial leaf surface (left, center and right sides), avoiding the branching veins, covering $0.71 \mathrm{~cm}^{2}$ of leaf area per reading. A mean $\mathrm{CCI}$ value per main plant leaf was determined in each growth row.

\section{Oxalic acid content}

Total oxalates, including water-soluble and water-insoluble oxalates, were quantified on all the dry corm and shoot flours. The oxalic acid $\left[(\mathrm{COOH})_{2}\right]$ is a dicarboxylic acid, and it can be oxidized to carbon dioxide and water by potassium permanganate and by ferric and ceric salts. Oxalic acid can form acidic and neutral soluble salts when combined with sodium $\left(\mathrm{Na}^{+}\right)$, potassium $\left(\mathrm{K}^{+}\right)$and iron $\left(\mathrm{Fe}^{2-}\right)$, or insoluble salts when combined with calcium $\left(\mathrm{Ca}^{2+}\right)$ (Franceschi and Horner 1980). When treated with hydrochloric acid, the oxalic acid from flour is reduced to glyoxylic acid, and then into glycolic acid, being precipitated and titrated with a standard potassium permanganate solution, as described below according to AOAC (1990), Oke (1965) and Dye (1956) method modifications, and with Fatoki (1994) recommendations.

Exactly $0.4 \mathrm{~g}$ of corm and shoot flours were solubilized in $30 \mathrm{~mL}$ of water, extracted with $2 \mathrm{~mL}$ of hydrochloric acid $(\mathrm{HCl}, 6.0 \mathrm{M})$, digested at $100{ }^{\circ} \mathrm{C}$, during $1 \mathrm{~h}$ in a water bath (Julabo SW22, Germany), made up to final volume of $50 \mathrm{~mL}$ and filtered with Whatman paper. The
Table 1 Taro (Colocasia esculenta (L.) Schott) accessions submitted to different watering regimes, to assess the plant's biochemical responses to drought conditions

\begin{tabular}{llll}
\hline Accession ID $^{\mathrm{a}}$ & Variety local name & Origin & Drought response $^{\mathrm{b}}$ \\
\hline 2056 & Listado & Canary Islands_La Palma & Moderate \\
2061 & Blanco Saucero & Canary Islands_Saucero & Tolerant \\
2210 & Roxo & Madeira Island & Moderate \\
2216 & Branco & Madeira Island & Tolerant \\
2232 & PExPH 15-6 BL/HW/08 & SPC, Fiji & Sensitive \\
2234 & C3-22 BL/PNG/11 & SPC, Fiji & Moderate \\
2239 & C3-22 BL/PNG/11 & SPC, Fiji & Sensitive \\
\hline
\end{tabular}

${ }^{a}$ Accessions identification number code, used by the ISOPlexis Genebank

${ }^{\mathrm{b}}$ Taro classification by drought-sensitive, moderate or tolerant response, obtained through their agro-morphologic screening, according to previous work of Ganança et al. (2018) performed in 2014 
filtrate was divided into two portions, methyl red indicator was added $\left(\mathrm{C}_{15} \mathrm{H}_{15} \mathrm{~N}_{3} \mathrm{O}_{2}\right)$ and titrated with ammonium hydroxide $\left(\mathrm{NH}_{4} \mathrm{OH}\right)$. Then, the filtrate was heated until $90{ }^{\circ} \mathrm{C}$, and subsequently cooled and filtered to remove the ferrous ion precipitate. The oxalic acid $\left[(\mathrm{COOH})_{2}\right]$ was precipitated as $\mathrm{CaOx}$ by adding $2 \mathrm{~mL}$ of calcium chloride $\left(\mathrm{CaCl}_{2}, 5 \%\right)$, and was left overnight at $5{ }^{\circ} \mathrm{C}$. The filtrate was centrifuged (Eppendorf Centrifuge 5430R, Hamburg) at $1438 \mathrm{~g}$ for $5 \mathrm{~min}$, the supernatant was decanted, and the precipitate was treated with boiling sulfuric acid $\left(\mathrm{H}_{2} \mathrm{SO}_{4}, 20 \%\right)$. Oxalate concentration was quantified by titration with a standard potassium permanganate solution $\left(\mathrm{KMnO}_{4}, 0.05 \mathrm{M}\right)$. The extraction with boiling $\mathrm{H}_{2} \mathrm{SO}_{4}$ gave the insoluble $\mathrm{CaOx}$ content, and the decanted supernatant gave the total acid soluble oxalates $(S-\mathrm{Ox})$, whose calculations were based according to Dye (1956) formulation (Eq. 1). The total oxalates $(T-\mathrm{Ox})$ was quantified according to Holloway et al. (1989) (Eq. 2). Each sample was analyzed in triplicate and all data are expressed as $\mathrm{mg} / 100 \mathrm{~g}$ dry flour.

Oxalate content $(\mathrm{CO}, \mathrm{mg} / 100 \mathrm{~g})=\left(T \times \mathrm{Vme} \times 3 \times 10^{5}\right) /(5 \times \mathrm{mf})$,

where $T$ is the titer of $\mathrm{KMnO} 4(\mathrm{~mL}), \mathrm{Vme}$ is the volumemass equivalent between $0.05 \mathrm{M} \mathrm{KMnO}_{4}$ and anhydrous oxalic acid (i.e., $1 \mathrm{~mL}$ of $0.05 \mathrm{M} \mathrm{KMnO}_{4}$ solution is equivalent to $0.00225 \mathrm{~g}$ anhydrous oxalic acid), 3 is the dilution factor, 5 is the molar equivalent of $\mathrm{KMnO} 4$ redox reaction in oxalate, and $\mathrm{mf}$ is the mass of flour used.

$T-$ Ox $(\mathrm{mg} / 100 \mathrm{~g})=\mathrm{CaOx}+S-\mathrm{Ox}$.

The method accuracy was validated through recovery index percentage of the oxalic acid (Van Reeuwijk et al. 1998). The samples were spiked with 2 and $5 \mathrm{mg}$ of oxalic acid ( $S-O x)$ in $400 \mathrm{mg}$ of corm and shoot flours, respectively. All the samples, as well the spikes, were analyzed five times. The recovery index ranged between 90 and $95 \%$ for the corms, and between 99 and 102\% for the shoots. Fatoki (1994) reported oxalic acid recoveries of 97-99\% from dry, finely ground vegetables, using a similar precipitation method.

\section{Nitrogen and crude protein content}

Total protein content was determined for all the dry corm and shoot flours by the Kjeldahl method with the quantification of total nitrogen, using a distillation and titration automatic unit (Velp Scientifica UDK 152, Italy). The factor Nx6.25 was applied to convert the total nitrogen to crude protein content (AOAC 2005). The analyses were performed in triplicate, and the values were expressed in $\mathrm{g} / 100 \mathrm{~g}$ dry flour.

\section{Starch content}

Starch was extracted from all the dry corm and shoot flours, according to Hodge and Hofreiter (1962). Starch soluble (Merck, Germany) was used as standard for quantitative estimation at $630 \mathrm{~nm}$, using a spectrophotometer UV/Vis (Shimadzu, 2401 PC, Japan) with the UVProbe 2.52 software. The analyses were performed in triplicate, and the values were expressed in $\mathrm{g} / 100 \mathrm{~g}$ dry flour.

\section{Swelling power and solubility of starch content}

The quality of the grain starch was determined according to Tattiyakul et al. (2006), with minor changes. Exactly $0.2 \mathrm{~g}$ of corm flours $\left(M_{0}\right)$ were homogenized in water and poured into a shaking water bath (Julabo SW22, Germany) at $80{ }^{\circ} \mathrm{C}$, until obtaining a gelatinized dispersion (approximately $45 \mathrm{~min}$ ). The gelatinized dispersion was centrifuged (Eppendorf Centrifuge 5430R, Hamburg) at $3000 \mathrm{~g}$ during $15 \mathrm{~min}$. The soluble starch granules (supernatant) were decanted and dried until a constant weight (MS) using an air oven at $100{ }^{\circ} \mathrm{C}$ (Memmert UF260, Germany). The swollen starch granules (MSW) (pellet) were weighted (Precisa ES225 SM-DR, Switzerland). The water solubility (WS) and swelling power (SP) were calculated according to the following Eqs. 3 and 4, in triplicate, and the values were expressed in $\mathrm{g} / \mathrm{g}$ dry flour.

$\mathrm{WS}=\mathrm{MS} / M_{0}$,

$\mathrm{SP}=\mathrm{MSW} /\left[M_{0} x(1-\mathrm{WS})\right]$.

\section{Statistical analysis}

The results are represented as the main average of taro corms and shoots of three control vs three drought individual rows, expressed in a dry weight basis. All samples were statistically evaluated with SPSS version 23.0 for Mac, for Pearson correlations and one-way ANOVA $(p \leq 0.05)$. The MVSP version 3.1 for Windows was used for principal component analysis (PCA).

\section{Results and discussion}

\section{Whole-plant oxalate content}

About $90 \%$ of the total calcium in the plant tissue can be found as oxalate salt (Nakata 2003). The overall intensity of root crops acridity by $\mathrm{CaOx}$ can change depending on exposure to drought and genetic factors (Sharma and Kaushal 2016; Libert and Franceschi 1987). The mean values of Total-Ox (T-Ox), Soluble-Ox $(S-O x)$ and $\mathrm{CaOx}$ 
Table 2 Variation of biochemical traits in the taro corms submitted to different irrigation regimes

\begin{tabular}{|c|c|c|c|c|c|c|c|}
\hline Corms & $T-\mathrm{Ox}^{\mathrm{a}, \mathrm{b}}$ & $S-\mathrm{Ox}$ a,b & $\mathrm{CaOx}^{\mathrm{a}, \mathrm{b}}$ & $\mathrm{CP}^{\mathrm{a}, \mathrm{b}}$ & $\mathrm{St}^{\mathrm{a}, \mathrm{b}}$ & $\mathrm{SWS}^{\mathrm{a}}$ & $\mathrm{SSP}^{\mathrm{a}}$ \\
\hline \multicolumn{8}{|l|}{2056} \\
\hline Control & $312.2 \pm 42.2$ & $41.1 \pm 12.6$ & $271.2 \pm 44.1$ & $3.8 \pm 0.1$ & $53.1 \pm 1.0$ & $0.20 \pm 0.0$ & $15.5 \pm 1.1$ \\
\hline Drought & $528.1 \pm 64.9$ & $59.4 \pm 20.4$ & $468.8 \pm 69.3$ & $4.5 \pm 0.1$ & $45.4 \pm 0.8$ & $0.19 \pm 0.0$ & $14.4 \pm 0.8$ \\
\hline \multicolumn{8}{|l|}{2061} \\
\hline Control & $327.1 \pm 135.4$ & $56.9 \pm 3.9$ & $270.2 \pm 135.8$ & $4.0 \pm 0.1$ & $46.3 \pm 0.9$ & $0.21 \pm 0.0$ & $17.8 \pm 0.4$ \\
\hline Drought & $295.8 \pm 61.0$ & $31.0 \pm 0.2$ & $264.8 \pm 60.8$ & $5.0 \pm 0.1$ & $46.6 \pm 1.5$ & $0.16 \pm 0.0$ & $17.7 \pm 0.1$ \\
\hline \multicolumn{8}{|l|}{2210} \\
\hline Control & $203.3 \pm 25.1$ & $16.6 \pm 4.2$ & $186.7 \pm 25.7$ & $3.9 \pm 0.1$ & $43.7 \pm 1.1$ & $0.19 \pm 0.0$ & $16.4 \pm 1.1$ \\
\hline Drought & $260.4 \pm 56.5$ & $28.7 \pm 6.3$ & $231.7 \pm 52.2$ & $5.4 \pm 0.0$ & $44.7 \pm 1.0$ & $0.20 \pm 0.0$ & $15.6 \pm 0.6$ \\
\hline \multicolumn{8}{|l|}{2216} \\
\hline Control & $210.5 \pm 52.1$ & $25.8 \pm 11.6$ & $184.7 \pm 44.7$ & $7.4 \pm 0.1$ & $45.6 \pm 2.2$ & $0.14 \pm 0.0$ & $11.8 \pm 0.6$ \\
\hline Drought & $224.4 \pm 50.5$ & $39.6 \pm 13.8$ & $184.7 \pm 41.5$ & $8.2 \pm 0.2$ & $43.3 \pm 1.8$ & $0.14 \pm 0.0$ & $12.0 \pm 1.5$ \\
\hline \multicolumn{8}{|l|}{2232} \\
\hline Control & $153.2 \pm 36.4$ & $28.4 \pm 4.9$ & $124.8 \pm 39.7$ & $3.8 \pm 0.2$ & $48.1 \pm 2.1$ & $0.18 \pm 0.0$ & $17.7 \pm 1.0$ \\
\hline Drought & $226.1 \pm 25.2$ & $36.0 \pm 4.3$ & $190.1 \pm 25.4$ & $4.7 \pm 0.0$ & $40.7 \pm 1.1$ & $0.21 \pm 0.1$ & $16.9 \pm 1.0$ \\
\hline \multicolumn{8}{|l|}{2234} \\
\hline Control & $353.4 \pm 23.3$ & $55.7 \pm 4.5$ & $297.7 \pm 27.7$ & $3.5 \pm 0.0$ & $54.6 \pm 0.9$ & $0.14 \pm 0.0$ & $17.0 \pm 0.7$ \\
\hline Drought & $379.2 \pm 113.1$ & $84.1 \pm 37.5$ & $295.1 \pm 84.6$ & $3.0 \pm 0.0$ & $52.6 \pm 0.6$ & $0.20 \pm 0.0$ & $16.9 \pm 1.4$ \\
\hline \multicolumn{8}{|l|}{2239} \\
\hline Control & $251.4 \pm 55.7$ & $27.0 \pm 7.9$ & $224.4 \pm 54.8$ & $5.0 \pm 0.0$ & $47.7 \pm 1.3$ & $0.15 \pm 0.0$ & $11.3 \pm 0.6$ \\
\hline Drought & $384.9 \pm 88.7$ & $25.8 \pm 3.1$ & $359.1 \pm 91.0$ & $6.1 \pm 0.0$ & $43.0 \pm 2.1$ & $0.15 \pm 0.0$ & $12.9 \pm 1.1$ \\
\hline \multicolumn{8}{|l|}{ Mean } \\
\hline Control & 258.7 & 35.9 & 222.8 & 4.5 & 48.4 & 0.17 & 15.4 \\
\hline Drought & 328.4 & 43.5 & 284.9 & 5.3 & 45.2 & 0.18 & 15.2 \\
\hline \multicolumn{8}{|l|}{ Min } \\
\hline Control & 153.2 & 16.6 & 124.8 & 3.5 & 43.7 & 0.14 & 11.3 \\
\hline Drought & 224.4 & 25.8 & 184.7 & 3.0 & 40.7 & 0.14 & 12.0 \\
\hline \multicolumn{8}{|l|}{ Max } \\
\hline Control & 353.4 & 56.9 & 297.7 & 7.4 & 54.6 & 0.21 & 17.8 \\
\hline Drought & 528.1 & 84.1 & 468.8 & 8.2 & 52.6 & 0.21 & 17.7 \\
\hline
\end{tabular}

Control is well-watered, drought is severe stress

Data are expressed in dry weight basis, and represents the mean \pm SD of three independent lines replications per acc., with total mean, minimum and maximum per trait

$T$ - $O x$ total oxalates $(\mathrm{mg} / 100 \mathrm{~g}), S$ - $O x$ soluble oxalates $(\mathrm{mg} / 100 \mathrm{~g}), \mathrm{CaO} x$ calcium oxalate $(\mathrm{mg} / 100 \mathrm{~g}), C P$ crude protein $(\mathrm{g} / 100 \mathrm{~g}), S t$ starch content $(\mathrm{g} / 100 \mathrm{~g}), S W S$ starch solubility in water $(\mathrm{g} / \mathrm{g}), S S P$ starch swelling power $(\mathrm{g} / \mathrm{g})$

${ }^{\text {a }}$ Significant differences between accessions (ANOVA, $p \leq 0.01$ )

${ }^{\mathrm{b}}$ Significant differences between control and drought stress conditions (ANOVA, $p \leq 0.05$ ) on drought-stressed accessions increased slightly in the corms (Table 2) and decreased in the shoots (Table 3). The corms had a $T-\mathrm{Ox}$ average value of approximately $259 \mathrm{mg} / 100 \mathrm{~g}$ in control conditions, with $27 \%$ increase to $328 \mathrm{mg} / 100 \mathrm{~g}$ in drought conditions (Table 2). The main fraction of $T-\mathrm{Ox}$ value was essentially composed by $\mathrm{CaOx}$, which increased $28 \%$ from 223 to $285 \mathrm{mg} / 100 \mathrm{~g}$ between control and stress conditions. The $\mathrm{CaOx}$ content was higher than the $182-200 \mathrm{mg} / 100 \mathrm{~g}$ range obtained by Tattiyakul et al. (2006), and lower than the $691 \mathrm{mg} / 100 \mathrm{~g}$ registered by Iwuoha and Kalu (1995), both evaluated in non-stressed corm flours. On the other hand, the $S$-Ox had the lowest content in all corms, ranging between approximately 36 and $44 \mathrm{mg} / 100 \mathrm{~g}$, for control and stress conditions (Table 2).

The $T-\mathrm{Ox}$ average value in shoots shows the opposite variation, decreasing $17 \%$ from approximately $322 \mathrm{mg} / 100 \mathrm{~g}$ in non-stress conditions to $268 \mathrm{mg} / 100 \mathrm{~g}$ in drought conditions. The mean $\mathrm{CaOx}$ content decreased $17 \%$ from 268 to $222 \mathrm{mg} / 100 \mathrm{~g}$ between control and stress conditions. The $S$-Ox had also the lowest content in shoots, decreasing $15 \%$ between approximately 54 and $46 \mathrm{mg} / 100 \mathrm{~g}$ for control and drought conditions (Table 3). 
Table 3 Variation of biochemical traits in the taro shoots submitted to different irrigation regimes

\begin{tabular}{|c|c|c|c|c|c|c|}
\hline Shoots & $T-\mathrm{Ox}^{\mathrm{a}}$ & $S-O x^{\mathrm{a}, \mathrm{b}}$ & $\mathrm{CaOx}^{\mathrm{a}, \mathrm{b}}$ & $\mathrm{CP}^{\mathrm{a}, \mathrm{b}}$ & $\mathrm{St}^{\mathrm{a}}$ & $\mathrm{CCI}^{\mathrm{a}}$ \\
\hline \multicolumn{7}{|l|}{2056} \\
\hline Control & $427.3 \pm 195.9$ & $84.1 \pm 20.4$ & $343.2 \pm 179.4$ & $9.8 \pm 0.0$ & $17.6 \pm 0.6$ & $37.4 \pm 7.5$ \\
\hline Drought & $358.8 \pm 149.4$ & $62.4 \pm 1.0$ & $296.3 \pm 150.4$ & $11.7 \pm 0.3$ & $14.3 \pm 1.1$ & $38.7 \pm 15.6$ \\
\hline \multicolumn{7}{|l|}{2061} \\
\hline Control & $187.4 \pm 31.7$ & $51.7 \pm 3.4$ & $135.7 \pm 28.3$ & $11.2 \pm 0.1$ & $9.4 \pm 0.8$ & $40.3 \pm 2.0$ \\
\hline Drought & $204.1 \pm 27.3$ & $25.6 \pm 9.9$ & $178.6 \pm 20.2$ & $10.7 \pm 0.1$ & $9.6 \pm 0.5$ & $43.4 \pm 6.8$ \\
\hline \multicolumn{7}{|l|}{2210} \\
\hline Control & $354.1 \pm 66.6$ & $52.8 \pm 6.0$ & $301.3 \pm 70.6$ & $12.9 \pm 0.1$ & $12.8 \pm 0.5$ & $38.3 \pm 7.9$ \\
\hline Drought & $237.3 \pm 30.6$ & $27.0 \pm 6.4$ & $210.3 \pm 37.1$ & $15.1 \pm 0.0$ & $10.0 \pm 0.9$ & $46.9 \pm 13.4$ \\
\hline \multicolumn{7}{|l|}{2216} \\
\hline Control & $193.7 \pm 43.1$ & $40.3 \pm 9.0$ & $153.3 \pm 35.1$ & $12.6 \pm 0.0$ & $7.5 \pm 0.5$ & $41.3 \pm 4.3$ \\
\hline Drought & $154.3 \pm 9.5$ & $34.6 \pm 4.4$ & $119.7 \pm 7.2$ & $13.8 \pm 0.0$ & $7.3 \pm 0.5$ & $44.8 \pm 13.7$ \\
\hline \multicolumn{7}{|l|}{2232} \\
\hline Control & $363.5 \pm 29.8$ & $37.8 \pm 2.9$ & $325.7 \pm 32.2$ & $9.9 \pm 0.1$ & $12.4 \pm 1.6$ & $18.6 \pm 7.0$ \\
\hline Drought & $275.0 \pm 24.5$ & $50.7 \pm 14.7$ & $224.3 \pm 13.9$ & $13.2 \pm 0.0$ & $11.8 \pm 0.6$ & $16.1 \pm 6.1$ \\
\hline \multicolumn{7}{|l|}{2234} \\
\hline Control & $528.2 \pm 33.9$ & $82.6 \pm 42.2$ & $445.6 \pm 23.2$ & $15.2 \pm 0.1$ & $11.1 \pm 0.8$ & $40.7 \pm 16.5$ \\
\hline Drought & $388.7 \pm 100.5$ & $89.2 \pm 29.0$ & $299.5 \pm 75.6$ & $11.8 \pm 0.1$ & $10.6 \pm 0.3$ & $30.8 \pm 10.0$ \\
\hline \multicolumn{7}{|l|}{2239} \\
\hline Control & $200.7 \pm 94.2$ & $29.0 \pm 7.5$ & $171.7 \pm 91.8$ & $8.6 \pm 0.3$ & $9.2 \pm 0.8$ & $12.4 \pm 3.6$ \\
\hline Drought & $260.0 \pm 106.9$ & $34.4 \pm 12.2$ & $225.6 \pm 94.7$ & $10.8 \pm 0.0$ & $10.6 \pm 2.1$ & $12.7 \pm 5.2$ \\
\hline \multicolumn{7}{|l|}{ Mean } \\
\hline Control & 322.1 & 54.0 & 268.1 & 11.5 & 11.4 & 32.7 \\
\hline Drought & 268.3 & 46.3 & 222.0 & 12.4 & 10.6 & 33.3 \\
\hline \multicolumn{7}{|l|}{ Min } \\
\hline Control & 187.4 & 29.0 & 135.7 & 8.6 & 7.5 & 12.4 \\
\hline Drought & 154.3 & 25.6 & 119.7 & 10.7 & 7.3 & 12.7 \\
\hline \multicolumn{7}{|l|}{ Max } \\
\hline Control & 528.2 & 84.1 & 445.6 & 15.2 & 17.6 & 41.3 \\
\hline Drought & 388.7 & 89.2 & 299.5 & 15.1 & 14.3 & 46.9 \\
\hline
\end{tabular}

Control is well-watered, drought is severe stress

Data are expressed in dry weight basis, and represents the mean \pm SD of three independent lines replications per acc., with total mean, minimum and maximum per trait

$T$ - $O x$ total oxalates $(\mathrm{mg} / 100 \mathrm{~g}), \mathrm{S}$ - $\mathrm{Ox}$ soluble oxalates $(\mathrm{mg} / 100 \mathrm{~g}), \mathrm{CaO} x$ calcium oxalate $(\mathrm{mg} / 100 \mathrm{~g}), C P$ crude protein $(\mathrm{g} / 100 \mathrm{~g})$, St starch content $(\mathrm{g} / 100 \mathrm{~g}), C C I$ chlorophyll content index

${ }^{\text {a }}$ Significant differences between accessions (ANOVA, $p \leq 0.01$ )

${ }^{\mathrm{b}}$ Significant differences between control and drought stress conditions (ANOVA, $p \leq 0.05$ )
Different accessions showed different behavior in oxalate production, accumulation and mobilization between corm and shoot organs. The $S$-Ox (as oxalic acid) and $\mathrm{CaOx}$ increase in corms and decrease in shoots during drought stress can be associated with the regulation of plant osmotic pressure by oxalate precipitation, with $\mathrm{CaOx}$ storage as insoluble oxalate salt at the root organs, and subsequent oxalate excretion into the environment, according to Nakata (2003). In general, the biochemical most tolerant showed less $\mathrm{CaOx}$ in the corms, in both control and drought conditions. During drought, they increased $\mathrm{CaOx}$ very slightly and mobilized it from shoots to corms as the better osmotic balance response, relatively to the sensitive ones. The regulation of the $S$-Ox and $\mathrm{CaOx}$ equilibrium allows changing tissues turgidity, and increasing the efficiency of water absorption under water scarcity. The most sensitive ones had naturally higher $\mathrm{CaOx}$, with a higher accumulation in both tissues during drought, which is more difficult for the plant to equilibrate/eliminate this insoluble salt during stress, thus compromising the efficiency of water absorption. Although, this role of the $S$ $\mathrm{Ox}$ and $\mathrm{CaOx}$ system in the tissue should be understood as complementary to other plant osmoprotectant systems. 
The corms from acc. 2056 showed the highest increase of $\mathrm{CaOx}$ accumulation under drought, from 271 to $469 \mathrm{mg} / 100 \mathrm{~g}$. Corms of acc. 2216 practically unchanged the $\mathrm{CaOx}$, standing in the $185 \mathrm{mg} / 100 \mathrm{~g}$, meanwhile acc. 2061 and 2234 slightly decreased the $\mathrm{CaOx}$ content in response to water scarcity. Accessions 2232 and 2210 had the lowest $\mathrm{CaOx}$ content variation, $125-190 \mathrm{mg} / 100 \mathrm{~g}$ and $187-232 \mathrm{~g} / 100 \mathrm{~g}$ in corms under non-stress and stress conditions, respectively (Table 2).

The shoots showed a $S$-Ox and $\mathrm{CaOx}$ decrease in response to drought. Possibly, during stress, the oxalate was mobilized from the shoots to the corms to be excreted as response to drought by osmotic pressure regulation. The shoots from acc. 2234 had the highest $\mathrm{CaOx}$ decrease, from 446 to $300 \mathrm{mg} / 100 \mathrm{~g}$. Meanwhile, in acc. 2061 and 2239 shoots, the $\mathrm{CaOx}$ content increased with drought, from 136 to 179 , and 172 to $226 \mathrm{mg} / 100 \mathrm{~g}$, respectively.

The acc. 2210 showed the best drought response, according to the amount of $\mathrm{CaOx}$ precipitation and its mobilization between organs, for further excretion in case of plant need. Acc. 2239 presented loss of $\mathrm{CaOx}$ in both organs, which suggests that it does not have the osmotic regulation by $\mathrm{CaOx}$ precipitation as drought response.

All the studied taro plants were not safe for raw consumption because of the high $\mathrm{CaOx}$ content, exceeding the allowed limit of $71 \mathrm{mg} / 100 \mathrm{~g}$ in food (Kumoro et al. 2014). The insoluble oxalate values are 3 and 4 times higher than the allowable value for the corms and shoots, which affects negatively the taro nutritional quality.

\section{Crude protein accumulation}

Drought stress leads to the crude protein content increasing, due to synthesis of high molecular weight proteins as a drought resistance response, according to Osuagwu and Edeoga (2013). Accordingly, taro plants slightly increased the protein content from the corms and shoots, when droughtstressed. The corms had the biggest increase of protein accumulation during stress, although the protein content in control conditions was 7\% higher in the shoots than in the corms (Tables 2, 3). Sharma and Kaushal (2016) only registered $4 \%$ higher protein content in the leaves, relatively to nonstressed corms. The corm average protein content increased from $4 \mathrm{~g}$ in control to $5 \mathrm{~g} / 100 \mathrm{~g}$ in drought conditions. The accession 2210 had the highest protein increase, from 3 to $5 \mathrm{~g} / 100 \mathrm{~g}$. Meanwhile, acc. 2216 showed the highest protein content, that increased from 7 to $8 \mathrm{~g} / 100 \mathrm{~g}$ in response to drought. On the other hand, in acc. 2234, the drought seemed to induce a slight decrease of the corm protein content, from 3.5 to $3 \mathrm{~g} / 100 \mathrm{~g}$ (Table 2). These results are in accordance with the Tattiyakul et al. (2006) work, which registered $5.1-8.7 \mathrm{~g} / 100 \mathrm{~g}$, and are higher than the Tattiyakul et al. (2007) study, which only had 1.6-1.9 g/100 g, both data in non-stressed dry corm flour, whose protein variation can be related with the different origin and environmental growth conditions.

The average crude protein of the stressed shoots increased from approximately 11 to $12 \mathrm{~g} / 100 \mathrm{~g}$, relatively to control. Accession 2210 had the highest shoot protein content, increasing from 13 to $15 \mathrm{~g} / 100 \mathrm{~g}$, approximately. Accession 2232 had the higher shoot protein increase, from approximately 10 to $13 \mathrm{~g} / 100 \mathrm{~g}$. Meanwhile, acc. 2234 was again the only one that presented a decreased protein content, from 15 to $12 \mathrm{~g} / 100 \mathrm{~g}$ (Table 3). Sharma and Kaushal (2016) reported a lower protein content, only $4 \mathrm{~g} / 100 \mathrm{~g}$ in nonstressed taro leaves.

The effect of drought stress in corms and shoots leads to the synthesis of different drought-inducible proteins, like high molecular weight proteins, enabling the increase of the crude protein content (Osuagwu and Edeoga 2013). The corm proteins are associated with the regulation of cell defense and detoxification, meanwhile the proteins of the leaves are related to photosynthesis, with significant changes in expression during stress (Salehi-Lisar and Bakhshayeshan-Agdam 2016). Therefore, acc. 2210 had a better drought response, which could be related with higher drought-inducible proteins synthesis, and acc. 2234 had the weakest drought response, which could be related with the decrease of protein synthesis in both plant organs.

\section{Chlorophyll content index}

The studied taro accessions showed an increase in CCI values, when submitted to drought, with a mean value of 33. The CCI measurement of the leaves was done using a chlorophyll fluorescence measurement technique, which can indirectly imply the difference of the plant photosynthetic rate. This index was proven efficient and reproducible for the plant evaluation susceptibility to drought. It was used among cultivars with contrasting drought tolerance, by the comparison of the photosynthetic electron transport among them, where the higher the plant chlorophyll index, the better the plant resistance to drought (Salehi-Lisar and Bakhshayeshan-Agdam 2016; Tiwari and Mamrutha 2013). Accessions that increased the photosynthesis under severe drought conditions maintained their photosynthetic electron transport from water molecules, through light excitation of photosystem PSII (one of the major sources of ROS in plants). The more excitation of photosystem PSII through photons of light, the greater are the number of ionized chlorophyll molecules, and the more ATP and NADPH are generated (Salehi-Lisar and Bakhshayeshan-Agdam 2016).

Accession 2210 had the highest photosynthesis rate, with a CCI increase from 38 to 47. On the other hand, acc. 2232 and 2234 showed a decrease of their CCI content from nearly 19 to 16 , and 41 to 31, respectively (Table 3). Mabhaudhi 
and Modi (2015) evaluated the CCI of taro landraces, using the same technique, and observed that under drought stress, taro plants lowered down the CCI to down-regulate the photosynthesis in response to decreased intracellular $\mathrm{CO}_{2}$ availability resulting from stomatal closure.

As the CCI varies accordingly with the plant drought stress tolerance, acc. 2210 has the best photosynthetic adaptation to drought, followed by acc. 2061 and 2216, respectively. Accessions 2232 and 2234, on the other hand, decreased the CCI, presenting a more sensitive response to drought.

\section{Starch content and grain quality}

The taro corm is the main plant energy storage organ (through starch), and it shows highest content variation under stress, when compared with the shoots. During drought stress, there is an increase of starch hydrolysis, due to the need to supply energy and metabolites to protect the subcellular structures against water deficit (Burgess and Huang 2016). In average, the drought environment slightly decreased the taro starch content, from 48 to $45 \mathrm{~g} / 100 \mathrm{~g}$ for the corms, and about $11 \mathrm{~g} / 100 \mathrm{~g}$ for the shoots (Tables 2, 3). At corm level, acc. 2056 and 2232 had the highest starch decrease, between 53-45 and 48-41 g/100 g, respectively. Among the analyzed samples, acc. 2210 was the only one that showed a slight increase of the starch content due to drought stress, from 44 to $45 \mathrm{~g} / 100 \mathrm{~g}$, approximately (Table 2). The starch content is in accordance with Kaushal et al. (2015) for non-stressed taro corm flour, between 41.27 and $61.44 \mathrm{~g} / 100 \mathrm{~g}$.

The shoots had a starch decrease due to drought, with acc. 2056 going from nearly 18 to $14 \mathrm{~g} / 100 \mathrm{~g}$, followed by acc. 2210 with $13-10 \mathrm{~g} / 100 \mathrm{~g}$. The acc. 2239 was the only accession registering a starch increase in shoots, from 9 to $11 \mathrm{~g} / 100 \mathrm{~g}$, approximately (Table 3).

We also evaluated the quality of the corm starch grain variation under water scarcity. According to Kaushal et al. (2015) and Tattiyakul et al. (2007), the corm starch forms a hard coating layer, with high starch swelling power (SSP), and usually is composed by four-fifths of amylopectin (22 glucose units per molecule) and one-fifth of amylose (490 glucose units per molecule). The loss of starch content and increase of amylose to amylopectin ratio leads to starch solubility in water (SWS) and SSP decrease, which can compromise the quality and functional properties of the corm starch grain.

Accessions 2210, 2232 and 2234 increased the SWS content between control and stress conditions, from 0.19 to 0.20 , $0.18-0.21$ and $0.14-0.20 \mathrm{~g} / \mathrm{g}$, respectively. The acc. 2061 had the highest SWS decrease, between 0.21 and $0.16 \mathrm{~g} / \mathrm{g}$ (Table 2). Works of Tattiyakul et al. (2007) and Tattiyakul et al. (2006) registered a range of $0.06-0.13 \mathrm{~g} / \mathrm{g}$ SWS of dry taro flour, respectively, which corresponds to a low starch solubility in water.

The SSP alteration due to drought was very low, and the main changes were observed at acc. 2239, who increased from nearly 11 to $13 \mathrm{~g} / \mathrm{g}$, and acc. 2056 who decreased from nearly 16 to $14 \mathrm{~g} / \mathrm{g}$, corresponding to a low starch swelling power in water. Tattiyakul et al. (2006) and Kumoro et al. (2014) observed also a low starch swelling power, with $11.0-17.4 \mathrm{~g} / \mathrm{g}$ and $14.5 \mathrm{~g} / \mathrm{g}$ SSP in dry non-stressed taro flour.

Overall, the accessions had a small variation in the corm starch content and quality grain under drought. We observed that some starch hydrolysis occurred because of reserves mobilization, as a way to supply energy and metabolites for protection of the cellular structures against water deficit. The grain starch of the corms had also a low SWS and SSP. Accessions 2056 and 2232 applied this strategy of starch mobilization, as a mechanism of response to drought and metabolism maintenance under stress conditions, leading to a higher starch loss. However, acc. 2061 and 2210 showed a different trend: not lose corm starch by hydrolysis under stress; were able to maintain the photosynthesis and nutrients allocation efficiency; they supplied the energy and metabolites without recourse to starch hydrolysis. Despite this, only acc. 2210 maintained the quality and functional properties of the corm starch grain.

\section{Whole-plant variation}

To better understand the taro whole-plant response to water scarcity, by the role of the oxalate mechanism and its relation with the chlorophyll content index, protein accumulation and starch variation, the one-way ANOVA analysis was applied to evaluate their variance. Significant differences were found between accessions $(p \leq 0.01)$ and experimental variants (control and drought-stress conditions, $p \leq 0.05$ ) (Tables 2, 3).

Statistically significant correlations were found among the variables, demonstrating the consistency of the variation of oxalate content with the photosynthetic rate, carbohydrate metabolism and protein synthesis. The corm traits showed nine significant correlations. The strongest trait associations were observed between protein and SSP $(-0.60)$. Moderate correlations were found between protein and starch $(-0.46)$, and protein and SWS (-0.44) (Table 4). The shoots showed seven significant correlations. The strongest correlations were observed between starch and $T$-Ox (0.53), and starch and $\mathrm{CaOx}(0.52)$. Moderate correlations were found between $\mathrm{CCI}$ and protein (0.48), and starch and $S$-Ox (0.37) (Table 5).

The PCA analysis, based in the average values of biochemical and CCI analysis, showed little variation of the shoots between control and drought cases (Fig. 1b), with the corms displaying a higher dissimilarity between control 
Table 4 Pearson correlation coefficients of the biochemical traits from taro corms in control and drought stress conditions

\begin{tabular}{llllllll}
\hline Variables & 1 & 2 & 3 & 4 & 5 & 6 & 7 \\
\hline 1. $S$-Ox & - & & & & & \\
2. $\mathrm{CaOx}$ & $0.40^{\mathrm{a}}$ & - & & & & \\
3. $T$-Ox & $0.56^{\mathrm{a}}$ & $0.99^{\mathrm{a}}$ & - & & & \\
4. CP & $-0.31^{\mathrm{b}}$ & -0.10 & -0.15 & - & & \\
5. St & $0.38^{\mathrm{b}}$ & 0.02 & 0.09 & $-0.46^{\mathrm{a}}$ & - & \\
6. SWS & 0.17 & 0.07 & 0.09 & $-0.44^{\mathrm{a}}$ & 0.01 & - & \\
7. SSP & 0.19 & -0.06 & -0.01 & $-0.60^{\mathrm{a}}$ & 0.11 & $0.42^{\mathrm{a}}$ & - \\
\hline
\end{tabular}

$S$ - $O x$ soluble oxalates $(\mathrm{mg} / 100 \mathrm{~g}), \mathrm{CaOx}$ calcium oxalate $(\mathrm{mg} / 100 \mathrm{~g}), T$ - $O x$ total oxalates $(\mathrm{mg} / 100 \mathrm{~g}), C P$ crude protein $(\mathrm{g} / 100 \mathrm{~g}), S t$ starch content $(\mathrm{g} / 100 \mathrm{~g}), S W S$ starch solubility in water $(\mathrm{g} / \mathrm{g})$, SSP starch swelling power $(\mathrm{g} / \mathrm{g})$

${ }^{a}$ Correlation is significant at the 0.01 level (two-tailed)

${ }^{\mathrm{b}}$ Correlation is significant at the 0.05 level (two-tailed)

\begin{tabular}{lllllll}
\hline Variables & 1 & 2 & 3 & 4 & 5 & 6 \\
\hline 1. S-Ox & - & & & & \\
2. CaOx & $0.57^{\mathrm{a}}$ & - & & & \\
3. $T$-Ox & $0.70^{\mathrm{a}}$ & $0.99^{\mathrm{a}}$ & - & & \\
4. CP & 0.15 & 0.19 & 0.19 & - & - & \\
5. $\mathrm{St}$ & $0.37^{\mathrm{b}}$ & $0.52^{\mathrm{a}}$ & $0.53^{\mathrm{a}}$ & -0.25 & -0.01 & - \\
6. CCI & 0.15 & 0.09 & 0.11 & $0.48^{\mathrm{a}}$ & -0. \\
\hline
\end{tabular}

$\mathrm{S}$ - $\mathrm{O} x$ soluble oxalates $(\mathrm{mg} / 100 \mathrm{~g}), \mathrm{CaO} x$ calcium oxalate $(\mathrm{mg} / 100 \mathrm{~g}), T$ - $O x$ total oxalates $(\mathrm{mg} / 100 \mathrm{~g}), C P$ crude protein (g/100 g), St starch content (g/100 g), CCI chlorophyll content index

${ }^{\text {a }}$ Correlation is significant at the 0.01 level (two-tailed)

${ }^{\mathrm{b}}$ Correlation is significant at the 0.05 level (two-tailed)
Table 5 Pearson correlation coefficients of the biochemical and CCI traits from taro shoots in control and drought stress conditions

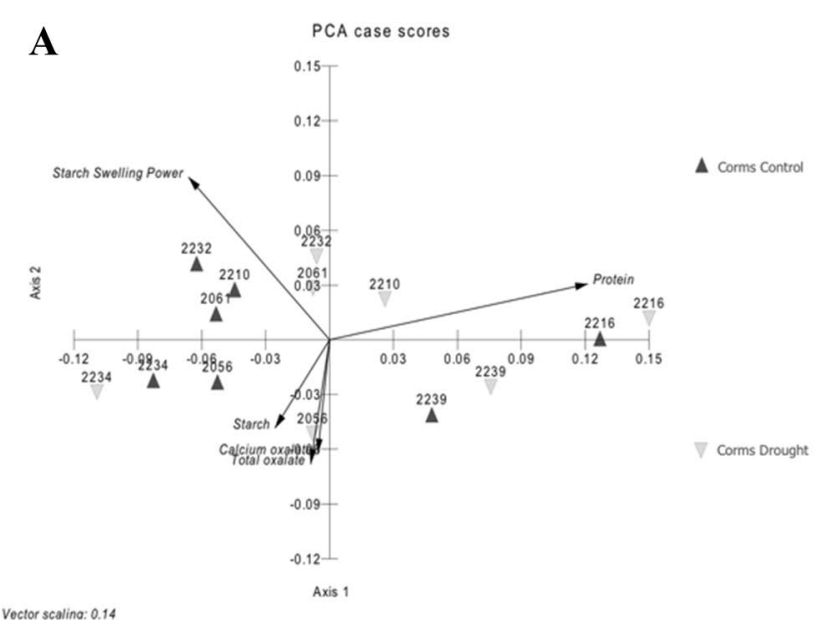

Fig. 1 Representation of the Euclidean biplot by principal component analysis (PCA), with spatial distribution of the C. esculenta accessions based in the average values of biochemical and CCI analysis in drought-stressed conditions. a The scattering distribution of the variables (traits) and case scores (taro accessions) evaluated in corms in

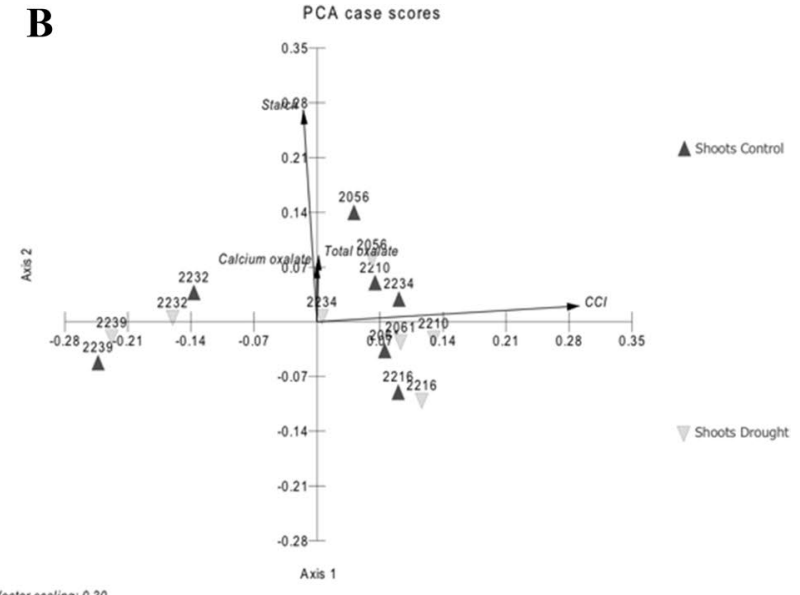

two PCA axes. b The representation of the spatial distribution of the variables (traits) and case scores (taro accessions) studied in shoots in two PCA axes. Data loge transformation was applied to all the traits (variables) in analysis. Control is well-watered, drought is severe stress 
and drought groups (Fig. 1a). The principal components explain $88.8 \%$ of variance observed in corms traits, with $76.0 \%$ at first and $12.8 \%$ at second axes, eigenvalues of 0.07 and 0.01 , respectively (Fig. 1a). The principal components explain $93.2 \%$ of cumulative variance of shoots traits, with $75.1 \%$ at first and $18.2 \%$ at second axes, eigenvalues of 0.23 and 0.06 , respectively (Fig. 1b). The accessions distribution agrees with observed variability of plant answers under drought stress.

The whole-plant multivariate analysis, analysis of variance and correlations among the traits variables, showed that the corm was the main organ affected by stress, displaying a higher variation in response to drought, with the leaves showing little variation. We observed that oxalic acid could be mainly a derivative product of the photosynthesis oxidative processes or carbohydrate metabolism, and was precipitated to $\mathrm{CaOx}$ for osmoregulation as insoluble oxalate. Overall, the $T$-Ox, $S$-Ox and $\mathrm{CaOx}$ synthesis, which expression increased in corms and decreased in shoots, had positive significant correlations. The shoots $\mathrm{CaOx}$ and $S$-Ox had a positive significant correlation with starch, which in turn was negatively correlated with protein content. According to Franceschi and Horner (1980), the oxidation of carbohydrates provided the energy for the reduction of nitrates into protein nitrogen, with oxalate synthesis as a direct subproduct. The increase in CCI and protein content had a positive moderate correlation, leading to an increase of plant tolerance to abiotic stress, as Salehi-Lisar and BakhshayeshanAgdam (2016), Mabhaudhi and Modi (2015) and Tiwari and Mamrutha (2013) mentioned.

The seven taro accessions in this study were previously classified as drought sensitive, moderate or tolerant, through stress indices calculated from agro-morphologic and yield screening (Ganança et al. 2018) (Table 1). The biochemical drought response could classify them as tolerant (acc. 2061, 2210 and 2216), moderately tolerant (acc. 2056 and 2232), and sensitive (acc. 2234 and 2239).

The acc. 2210, in this study, shows the better drought tolerance response: had the bigger $\mathrm{CaOx}$ precipitation and mobilization as osmotic response; the best photosynthetic adaptation with the highest CCI content and protein increase; the less starch hydrolysis, with less quality loss by SWS and SSP. However, this accession was classified as moderately tolerant by the previous assay of Ganança et al. (2018) (Table 1). Accessions 2216 and 2061 also showed to be tolerant to water scarcity, agreeing with the Ganança et al. (2018) classification (Table 1). The drought tolerance was mainly supported through CCI increase, high protein content and osmoregulation by $\mathrm{CaOx}$ precipitation. Accessions 2056 and 2232 were, from a biochemical point of view, moderately tolerant. However, acc. 2232 was previously classified as sensitive by Ganança et al. (2018) (Table 1). The moderate tolerance response was mainly observed through the starch hydrolysis ratio and oxalate osmoregulation. The acc. 2234 and 2239 had the most sensitive response to drought, being acc. 2234 previously classified as moderately tolerant by Ganança et al. (2018) (Table 1). These accessions showed less $\mathrm{CaOx}$ mobilization, decreased photosynthetic rate, with a slight increase of starch hydrolysis or protein synthesis as strategy for drought mitigation.

\section{Conclusion}

Variation in oxalate content by the taro plant was consistent with the photosynthetic rate, carbohydrate metabolism and protein synthesis, with significant correlations observed between parameters. Drought-tolerant accessions had good osmotic response by oxalate precipitation and mobilization from the shoots to the corms to be excreted as plant response to drought by osmotic pressure regulation, had photosynthetic adaptation by the highest CCI content and protein increase, and less starch hydrolysis and quality loss. Drought sensitive presented less mobilization of $\mathrm{CaOx}$, decreased photosynthetic rate, and slight increase starch hydrolysis or protein synthesis. All the corms in this study had high $\mathrm{CaOx}$ content, three times higher than the allowable value for the corms, and four times for the shoots, which affects negatively the whole-plant nutritional quality. Taro accessions were classified according to the biochemical drought response as tolerant for the accessions 2061, 2210 and 2216, followed by accessions 2056 and 2232 as moderate tolerant, and 2234 and 2239 as sensitive. The biochemical drought classification is in accordance for acc. 2061, 2216, 2056 and 2239, with the previous work from Ganança et al. (2018).

Author contribution statement CSSG performed the biochemical experiments, analyzed, interpreted, summarized all data generated from those experiments, and wrote the manuscript. JFTG designed the study for the drought assay, and helped in statistical analysis. VL and MAAPC coordinated the work and revised the manuscript.

Acknowledgements The authors acknowledge the Programa Operacional da Região Autónoma da Madeira-PO Madeira 14-20 (grant number M1420-01-0145-FEDER-000011, CASBio). The first author wishes to acknowledge the Agência Regional para o Desenvolvimento da Investigação Tecnologia e Inovação (ARDITI) for the financial support grant number M1420-09-5369-FSE-000001.

\section{References}

AOAC (1990) Association of official analytical chemists, official methods of analysis, 974.24, 15th edn. AOAC, Arlington, pp 993-994 AOAC (2005) Association of official analytical chemists, official methods of analysis, 945.18-B, 18th edn. AOAC, Gaithersburg 
Burgess P, Huang B (2016) Mechanisms of hormone regulation for drought tolerance in plants. In: Hossain MA, Wani SH, Bhattacharjee S, Burritt DJ, Tran L-SP (eds) Drought stress tolerance in plants: physiology and biochemistry, vol 1, 1st edn. Springer, Basel, pp 47

Dye WB (1956) Chemical studies on Halogeton Glomeratus. Weeds 1(4):55-60

Epron D, Dreyer E (1996) Starch and soluble carbohydrates in leaves of water-stressed oak saplings. Ann Sci Forestieres 53:263-268

Farooq M, Wahid A, Kobayashi N, Fujita D, Basra SMA (2009) Plant drought stress: effects, mechanisms and management. Agro Sustain Dev 29:185-212

Fatoki OS (1994) Determination of oxalic acid in vegetables. In: Linskens HF, Jackson JF (eds) Vegetables and vegetable products. Modern methods of plant analysis. Springer, Berlin, pp 161-166

Franceschi VR, Horner HT (1980) Calcium oxalate crystals in plants. Bot Rev 46(4):361-427

Ganança JFT, Freitas JGF, Nóbrega HGM, Rodrigues V, Antunes G, Rodrigues M, Pinheiro de Carvalho, MÂA, Lebot V (2015) Screening of elite and local taro (Colocasia esculenta) cultivars for drought tolerance. Proc Environ Sci 29:41-42

Ganança JFT, Freitas JGR, Nóbrega HGM, Rodrigues V, Antunes G, Gouveia CSS, Rodrigues M, Chaïr H, Pinheiro de Carvalho, MÂA, Lebot V (2018) Screening for drought tolerance in thirty three taro cultivars. Notulae Botanicae Horti Agrobotanici ClujNapoca 46(1):65-74

Hodge JE, Hofreiter BT (1962) Analysis and preparation of sugars. In: Whistler RL, Miller JNB (eds) Methods in carbohydrate chemistry, 6th edn. Academic Press, New York, pp 356-378

Holloway WD, Argall ME, Jealous WT, Lee JA, Bradbury JH (1989) Organic acids and calcium oxalate in tropical root crops. J Agric Food Chem 37(2):337-341

Iwuoha CI, Kalu FA (1995) Calcium oxalate and physico-chemical properties of cocoyam (Colocasia esculenta and Xanthosoma sagittifolium) tuber flours as affected by processing. Food Chem 54(1):61-66

Kaushal P, Kumar V, Sharma HK (2015) Utilization of taro (Colocasia esculenta): a review. J Food Sci Technol 52(1):27-40

Kumoro AC, Putri RDA, Budiyati CS, Retnowati DS (2014) Kinetics of calcium oxalate reduction in taro (Colocasia Esculenta) corm chips during treatments using baking soda solution. Proc Chem 9:102-112

Lebot V (2009) Tropical root and tuber crops: cassava, sweet potato, yams and aroids. In: Atherton J, Rees A (eds) Crop production science in horticulture series, vol 17. CAB International, Cambridge

Lebot V, Tuia V, Ivancic A, Jackson GVH, Saborio F, Reyes G, Rodriguez S, Robin G, Traoré L, Aboagye L, Onyeka J, van Rensburg W, Andrianavalona V, Mukherjee A, Prana MS, Ferraren D, Komolong B, Lawac F, Winter S, Pinheiro de Carvalho MÂA,
Iosefa T (2017) Adapting clonally propagated crops to climatic changes: a global approach for taro (Colocasia esculenta (L.) Schott). Genet Resour Crop Evol 65(2):591-606

Libert B, Franceschi VR (1987) Oxalate in crop plants. J Agric Food Chem 35(6):926-938

Mabhaudhi T, Modi AT (2015) Drought tolerance of selected South African Taro (Colocasia Esculenta L. Schott) landraces. Exp Agric 51(3):451-466

Nakata PA (2003) Advances in our understanding of calcium oxalate crystal formation and function in plants. Plant Sci 164(6):901-909

Oke OL (1965) Chemical studies of some Nigerian vegetables. Exp Agric 1:125-129

Oscarsson KV, Savage GP (2007) Composition and availability of soluble and insoluble oxalates in raw and cooked taro (Colocasia esculenta var. Schott) leaves. Food Chem 101(2):559-562

Osuagwu GGE, Edeoga HO (2013) The effect of water stress (drought) on the proximate composition of the leaves of Ocimum gratissimum (L) and Gongronema latifolium (Benth). Int J Med Aromat Plants 3(2):293-299

Prasad R, Shivay YS (2017) Oxalic acid/oxalates in plants: from selfdefence to phytoremediation. Curr Sci 112(8):110-112

Salehi-Lisar SY, Bakhshayeshan-Agdam H (2016) Drought stress in plants: causes, consequences, and tolerance. In Hossain MA et al (eds) Drought stress tolerance in plants-physiology and biochemistry, Chap. 1, vol 1. Springer, Basel, pp 1-17

Sharma HK, Kaushal P (2016) Introduction to tropical roots and tubers. In: Sharma HK et al (eds) Tropical roots and tubers-production, processing and technology. Wiley, Oxford, pp 1-22

Tattiyakul J, Asavasaksakul S, Pradipasena P (2006) Chemical and physical properties of flour extracted from taro Colocasia esculenta (L.) Schott grown in different regions of Thailand. SenseAsia 32:279-284

Tattiyakul J, Pradipasena P, Asavasaksakul S (2007) Taro Colocasia esculenta (L.) schott amylopectin structure and its effect on starch functional properties. Starch/Staerke 59(7):342-347

Temesgen M, Retta N (2015) Nutritional potential, health and food security benefits of Taro Colocasia Esculenta (L.): a review. Food Sci Qual Manag 36:23-30

Tiwari R, Mamrutha HM (2013) Precision phenotyping for mapping of traits for abiotic stress tolerance in crops. In: Salar RK et al (eds) Biotechnology: prospects and applications. Springer, Sirsa, pp 81-82

Van Reeuwijk LP, Houba VJG, Food and Agriculture Organization of the United Nations, International Soil Reference and Information Centre (1998) Guidelines for quality management in soil and plant laboratories, vol 222, 74th edn. Food and Agriculture Organization of the United Nations, International Soil Reference and Information Centre, Rome 